\title{
Strategies of Refusal Speech Act by Javanese Culture-based Students at Darul Ihsan Muhammadiyah Islamic Boarding School Sragen Indonesia
}

\author{
Harun Joko Prayitno ${ }^{1}$, Abdul Ngalim ${ }^{2}$, Muhammad Rohmadi ${ }^{3}$, Udik Riyanto ${ }^{4}$ \\ ${ }^{1,2}$ Faculty of Teacher Training and Education, Universitas Muhammadiyah Surakarta, Indonesia \\ ${ }^{3}$ Faculty of Teacher Training and Education, Universitas Sebelas Maret, Indonesia \\ ${ }^{4}$ Postgraduate School, Universitas Muhammadiyah Surakarta, Indonesia
}

\section{Article Info}

Article history:

Received Mar 17, 2018

Revised Apr 21, 2018

Accepted Jun 26, 2018

\section{Keywords:}

Character building

Polite values

Politeness

Refusal speech act

\begin{abstract}
The research aims at (a) describing the strategies and identifying the levels of refusal speech act in politeness and (b) formulating the internalization of polite values in a process of the Javanese culture-based students' character building. It was conducted at Darul Ihsan Muhammadiyah Islamic Boarding School Sragen, Central Java, Indonesia. It employed a descriptive and qualitative, and analytic, critic, and holistic approach. The data sources covered all the students (santri) and teachers (asatidz) in both formal and informal situations. The objects were the refusal speech acts, spoken in the communication at the school. The data were collected with the techniques of content analysis, in-depth interview, and observation. These were analyzed with a contextual-extralingual method. In conclusion, the results of the research show that: (a) the refusal speech act is performed through the indirect (63\%) and direct strategies (37\%), (b) the refusal speech act is spoken through indirect communication in politeness $(29 \%)$, impoliteness $(56 \%)$, disadvantage-benefit (3\%), authority (5\%), and option $(5 \%)$, and social distance (2\%), and (c) the internalization of the students' character building is performed in the forms of role model, habit, supervision, advice and suggestion, warning, and sanction. The dominant factors in the internalization process are closely related to the teachers' roles, Islamic Boarding School's circumstance, and politeness building in the learning process. The problems are closely related to the low understanding of politeness, heterogeneous students, and their habits.
\end{abstract}

Copyright () 2018 Institute of Advanced Engineering and Science. All rights reserved.

\section{Corresponding Author:}

Harun Joko Prayitno,

Faculty of Teacher Training and Education,

Universitas Muhammadiyah Surakarta.

Jl. Ahmad Yani, Pabelan, Tromol Pos1, Surakarta 57101, Indonesia.

email: harun.prayitno@ums.ac.id

\section{INTRODUCTION}

Islamic Boarding School (Pondok Pesantren/Pontren) is one of the educational institutions that integrate the general and Islamic educations. The life within such a school is heavily associated with the students' (santri) communication behaviors and attitudes which are tendentiously different from one another. Also, the students' different community culture will represent the diversity of speech act, particularly in relation with linguistic politeness and communication channels.

The difference or diversity of linguistic politeness is manifested in the strategies of rejection as the communication of refusal speech act (RSA). The strategies of refusal speech act contain linguistic politeness, especially RSA. The study discusses RSA that is conveyed among students, between students and staffs of boarding school, and between students and teachers. It is very interesting to study the diverse performances 
of RSA, in terms of the strategies and the level of politeness. Moreover, the circumstance of Islamic boarding school fosters the religiosity and obedience to older people (tawadhu). Hence, RSA is presumed as an inappropriate performance. Generally, a refusal speech act will be only used if a speech is intended to communicate positive values. For this, it is necessary to determine a refusal speech act that is appropriate to the positive politeness of speech act.

In relation to the background, the study emphasized on the strategies of refusal speech act (RSA) and their level of politeness. It is likely that a speech act performed by students in refusing orders, requests, and recommendations conveyed to the teachers or staffs of boarding school are entirely perceived as polite. The refusal acts may be communicated in these speeches: "Wait a minute", "No", "Later", "I'm tired", "I am preoccupied", and so on. These phenomena of RSA are conveyed by students to their teachers. Nevertheless, if those phenomena that are not linked to the context [1-3], they may be included in an impolite speech act [4].

The study of politeness is very crucial as suggested [5], [6]. In essence, the research of politeness examines a language use in a particular language community. Nowadays, linguistic politeness is inclined to be degraded from generation to generation in accordance with the ever-changing context and development of the industrial era [7]. Therefore, comprehensive studies are required in the education development, ranging from elementary to higher educations. The aim is to improve the deterioration of politeness among students, adolescents, and adulthood in accordance with a genuine culture of Indonesian community.

In fact, RSA among students is basically scalable. The degrees of politeness in speech act are classified into five types of scales: Disadvantage-benefit, Option, Indirectness scale, Authority, and Social Distance [8]. The results of the study are specifically explicated based on the pragmatic politeness scale developed by Leech [8].

\section{RESEARCH METHOD}

The main design of the study is included in a qualitative approach since it was conducted by describing the speech act in an Islamic boarding school context by utilizing natural methods. The qualitative research was employed by highlighting the deep comprehension of interaction among prevailing speech acts and investigating them inductively in the circumstance of Darul Islam Muhammadiyah Islamic Boarding School, Sragen, Central Java, Indonesia.

The subjects of the study were the students (santri) and teachers (asatidz) of Darul Islam Muhammadiyah Islamic Boarding School (DIMS) Sragen Indonesia. The objects of the research were the refusal speech act in a Javanese language empirically communicated among the students of the DIMS. It was attempted to attain the clarity of the data contained in the object of research (:gegenstand) [9], [10].

The data were in the form of qualitative data, which included the refusal speech acts in a Javanese language. The data collection holistically used a hearing technique, field note, and interview from April to October 2016. Also, the content analysis technique was included in the spoken and written language [9], [10]. The interview was used to relate a context to an individual, event, activity, organization, emotion, motivation, response or perception, degree and form of student's involvement, and so on. The aim was to construct those aspects as part of the past, and to project them with regard to expectations that may occur in the future.

The data was analyzed with a contextual-extralingual method as developed by Leech's degree of politeness. It is a method whose determinant is outside, detached, and excluded from the corresponding language (langue). The contextual method used was the pragmatic contextual sub-type [11]. It was employed to analyze refusal speech acts and the scale of politeness from students to teachers.

\section{RESULTS AND ANALYSIS}

The results of the study were classified into three sections, including describing 1) the strategies of RSA of students toward teachers, 2) the scale of politeness in students' RSA, and 3) the internalization of RSA among students of Darul Islam Muhammadiyah Islamic Boarding School based on a Javanese culture. In general, the study describes the strategies of RSA among students based on two contexts: academic or learning and Islamic teaching or education. The results indicate that the strategies of RSA among students are based on the academic context rather than that of Islamic teaching or education. In the context of Islamic teaching and education, it is found the rigid, omnipresent and mandatory principles. Meanwhile, those related to academic and learning process are an activity that should be developed and studied continually. Therefore, the RSA performed by the students of the Islamic boarding school neighborhood is mainly driven by and solely aimed to a scientific development and human welfare. Essentially, the results are relevant to the research by Kedves [12] and Ali [14]. 


\subsection{Strategies of Refusal Speech Acts}

The strategies of refusal speech act (RSA) were divided into two types of direct and indirect as shown in Figure 1. The data of the strategies of direct refusal speech acts are more dominant (63\%) than indirect ones (27\%). It may be caused by their association to academic, scientific, and learning development.

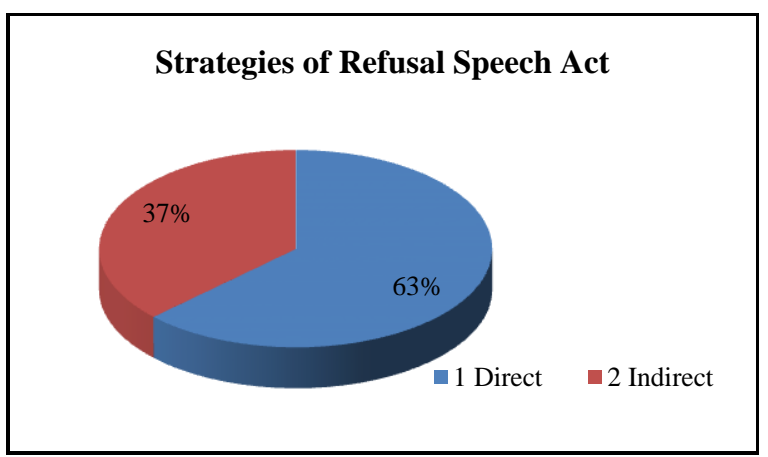

Figure 1. Strategies of RSA

\subsubsection{Strategies of Direct Refusal Speech Act}

The direct refusal speech acts were performed by students for making various responses. In general, it is realized in response to instruction, advice, invitation, and prohibition propounded by teachers, as shown in the context of conversation (1) below:

[1] A teacher commanded a student to come in front of the class because he spoke something disrespectfully.

$\begin{array}{ll}\text { Teacher } & : \text { "Tolong kamu Ikhlas maju ke sini! Tadi kamubi cara apa?" } \\ \text { Student } & : \text { "Emlas, please come here! What did you say?" } \\ & \text { "No, Sir!" } \\ \text { Teacher } & : \text { "Nanti setelah pelajaran ikut ustad ke BK!" } \\ & \text { "After the class, come to the counseling office!" } \\ \text { Student } & : \text { "Emoh ust, aku dipancing kaeog!" } \\ & \text { "No, Sir. Someone provoked me!" } \\ \text { Lingual Marker } & \text { : The word "emoh" (Javanese) signifies a refusal (meaning 'no') }\end{array}$

The direct refusal speech act for command conveyed by a teacher is the students' response. It occurred during the class when the teacher heard one of the students spoke disrespectfully. The teacher then asked the student to come in front of the class, but the student refused it impolitely by using a lingual marker of unwilling or no, which signifies an impolite response.

The various forms of direct refusal utterances used by the students are reported in Figure 2. Principally, there is vigilance in such acts. Figure 2 shows that most of students refuse any command or instruction, but relatively comply with advice and invitation. The results demonstrate the propensity of students in denying any discrete coercion. The advice and persuasion are the most appropriate methods to instruct the students to perform an action, especially in relation to a religious teaching.

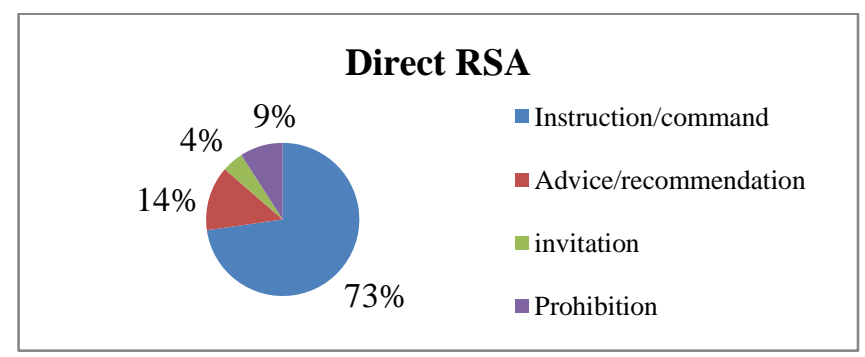

Figure 2. Diagram of direct RSA 


\subsubsection{Strategies of Indirect Refusal Speech Act}

The indirect refusal speech acts was divided into five sub-types in various contexts. The acts were used by the students in response to instruction/command, advice/recommendation, invitation, prohibition, and proposal. One of the excerpts of this speech act is shown in the speech (2) below:

[2] A teacher gave a reward for a student who had provided any assistance in the canteen located at SMA Trensains.

Teacher

: "Ini buat kamu untukjajan."

"Here for you if you want to buy something."

Student

: "Maaf ustadah, untuk ustadah saja."

Marker

"I'm sorry, Mam. I cannot accept it."

: "maaf"

Sorry.

The indirect RSA in (2) was uttered by a female student to her female teacher. The speech occurred when they were taking a rest in the canteen of SMA Trensains. At that time, she was willing to give a reward in the form of money to the student who had provided assistance. However, the student indirectly refused the reward by politely saying "sorry" as a lingual marker. It indicates an indirect speech act because it was propounded politely and was not signified a refusal marker.

Figure 3 shows the examples of the direct RSA, describing the act tends to be uttered by the students in response to the teachers' instruction/command. Most of them performed the indirect refusal speech acts $(54 \%)$ more frequently in response to the teachers' advice, invitation, prohibition, or offer.

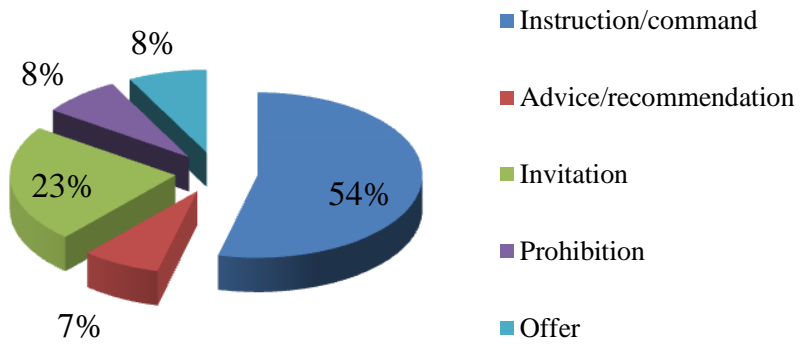

Figure 3. Diagram of indirect RSA

\subsection{The Scales of Refusal Speech Act}

\subsubsection{Indirectness Scale}

The principle of the indirectness scale occurs when the more direct the RSA is, the lower the degree of its politeness is. RSA performed by the students is generally in the form of statements. It indicates that in expressing a disagreement, the students have a propensity to utter it indirectly, instead of directly. It is expressed both in class and outside the class as shown by a student who impolitely refused to come in front of the class because he said something rudely.

[3] Explicature of speech act

Lingual marker

Implicature
: Ustad: "Tolong kamu Nak majuke sini! Tadi kamu bicara apa?"

Teacher: "Please come here! What did you say?"

Santri: "Emoh Ust!"

Teacher: "No, Sir!"

Ustad: "Nanti setelah pelajaran ikut ustad ke BK!"

Teacher: "You come with me to the counseling office after the class!"

Santri: "Emoh ust, aku dipancing kaekok"

Student: "Emoh, Sir. I did it because someone provoked me"

: "Emoh, aku diancing kae kok"

No, I did it because someone provoked me"

: The student gave reason that he said something rudely because his friend provoked him. 


\subsubsection{Disadvantage-benefit Scale}

The disadvantage-benefit scale is based on the fact that the more disadvantage the interlocutor is, the lower the degree of RSA is. The realization of RSA was performed by a student to a teacher with the intention of refusing a teacher's instruction to collect the assignment in the form of print out and bound paper. In responding the instruction of an Indonesia language teacher, the student conveyed an indirect speech act by uttering "Would you mind binding it, Sir?" In accordance with the disadvantage-benefit analysis, it is categorized as a form of speech that only benefits the speaker (student), but it is said to be disadvantages for the interlocutor (teacher).

[4] Explicature of speech act

Lingual marker

Implicature
Ustad: "Anak-anak, untuk tugas karya ilmiahnya besok dikumpulkan dalam bentuk print out dan dijilid ya!"

Santri: "Nanti ustad yang jilid ya."

Teacher: "For the assignment of scientific paper, you have to collect it tomorrow in the form of print out and bound paper!"

Student: "Would you mind biding it, Sir, Sir?"

Nanti ustad yang jilid

Would you mind binding it, Sir?

When an Indonesia language teacher instructed the students to compose and collect the assignment of scientific paper in the form of print out and bound paper, they responded it by indirectly declining the instruction to show their objection by asking the teacher to bind the paper.

\subsubsection{Optional Scale}

The principle of optional scale is the more unpleasant the RSA is, the more impolite the RSA is. The realization of RSA in (5) describes the students' strategies to refuse the teacher's instruction to answer the questions in the book by making options. The RSA merely contains two options, namely "right now" and "later", with the intention of indirectly refusing the teacher's instruction. Such an indirect RSA indicates the student attempted to refuse by giving options to the teacher.

[5] Explicature of speech act

Lingual marker

Implicature
Ustad: "Fitriana, tolongka mubaca dan jawab soal nomor 30!"

Santri: "Sekarang atau kapan Ust?"

Ustad: "Tahun depan saja!"

Teacher: "Fitriana, read and answer question number 30!"

Student: "Right now or later, Mam?"

Teacher: "Next year!"

: Sekarang atau kapan

Right now or later

A teacher asked a student to read and then answer a question. The student applied a way of refusal speech act by giving a lingual marker "right now or later?", which indicated an indirect refusal act by involving the interlocutor.

\subsubsection{Authority Scale}

The type of authority scale is based on the principle of the higher the authority centered on the speaker is, the lower the degree of RSA is and vice versa. The RSA in (6) describes when a teacher instructed a student for a presentation, but the student indirectly refused it by uttering "Sorry Ustad Udik, but I have presented my paper". The authority of approval over RSA conveyed by the student is not absolute. Thus, the RSA is still classified as polite.

[6]

Explicature of speech act

Lingual marker

Implicature
Ustad: "Selanjutnya, Nur Aini coba maju!"

Santri: "Maaf Ustad Udik, kan tadi sudah tadz."

Teacher: "Next, Nur Aini comes here!"

Student: "I'm sorry Ustad Udik, but I have presented my paper."

: Kan tadi sudah

I have presented it, haven't I?

: Such an indirect RSA by uttering "I'm sorry, but I have presented my paper" is a statement whose authority is back to the teacher as interlocutor. 


\subsubsection{Social Distance Scale}

The social distance scale emphasizes the use of RSA with wide social gap, but the use of RSA will be narrower, thus it decreases the degree of a RSA, and vice versa. The realization of RSA in (7) illustrates when a teacher wanted to give a reward in the form of money for student who helped her in the canteen cooperative service. However, the student indirectly refused the reward by stating "I'm sorry Mam, I cannot accept it". In the context of the utterance, even though the teacher perceived the student as her own child, but the speech act performed by the student demonstrated the existence of social distance. Therefore, the realization of RSA is classified as very polite.

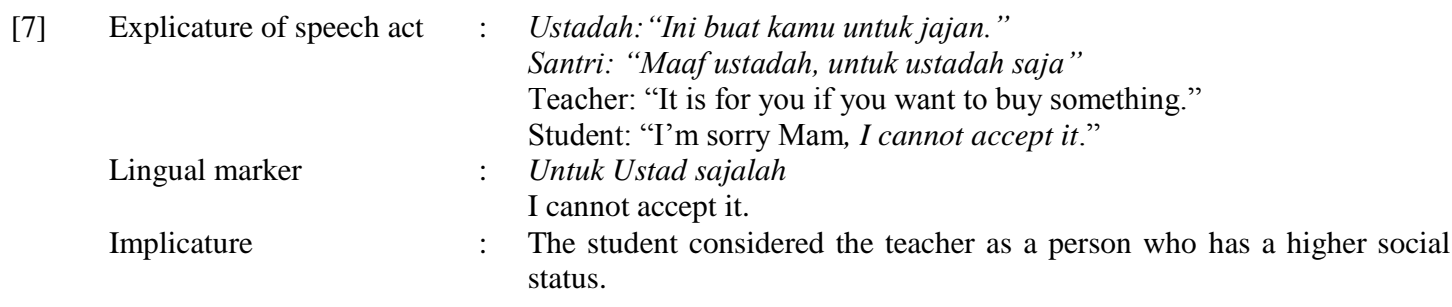

The realization of the diverse scales of RSA among the students of DIMS implies that the most dominant RSA is in the form of indirect strategies (56\%). It indicates that expressing their disagreement refusing, avoiding, or inhibiting, can be categorized in a relatively polite act. The strategies are performed merely for academic and learning activities, instead of refusing any instruction of Islamic teachings. The students perceive that the Islamic teachings are standard and it is in accordance with the provisions of Islamic law and therefore must be implemented. Meanwhile, the academic and learning activities are relative, thus there is open space to be responded by means of refusing, avoiding, or inhibiting if an instruction is not in accordance with the applicable academic and learning agreement (see Figure 4).

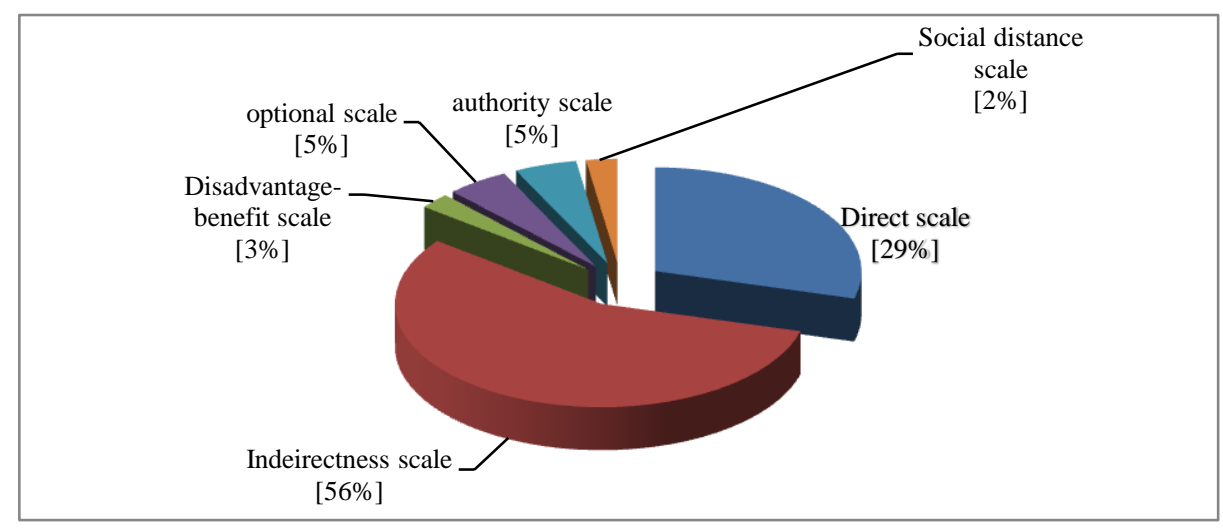

Figure 4. Diagram of general scale of RSA

\section{DISCUSSION}

Politeness is the most fundamental component to establish the students' identity and character in the boarding school environment. One form of politeness is closely related to a linguistic field such as expressing a refusal speech act (RSA). Such an act can be realized through various strategies $[14,15]$. The results of the research show that to establish and internalize the students' character building, several actions can be taken such as: (a) example (role model), (b) enculturation, (c) supervision, (d) suggestion, (e) admonition, and (f) sanctions. These are a central key to build the students' character and identity.

Furthermore, the results of the research state that the Javanese culture-based students are unfamiliar to the example and advice. The habituation, reprimand, and sanctions are very essential to build the students' identity and good character. Everything must be implemented and integrated intact. The results of the study are different from the previous researches, stating that an example (role mode) is a major factor in building the students' character.

The realization of RSA by the students is mostly to respond the teacher's instruction in the academic context and learning activities. The students' indirectness scale in realizing RSA will be higher if the teachers use the approach of suggestion and role model. The students feel that the form of suggestion is closer to social harmony in the character building. This strategy is important for educators to avoid politeness paradox

Strategies of Refusal Speech Act by Javanese Culture-based Students at Darul... (Harun Joko Prayitno) 
of pragmatism [16] a model for fostering students' creativity in the learning process [17] and inherent politeness in students $[18,19]$.

The important factors in an internalization process of the students' character building include (a) the teachers' role in the enculturation of politeness [20] in learning activities, (b) the polite-encouraged circumstance, and (c) the character building by learning in the classroom. Meanwhile, the inhibiting factors in an internalization of the students' character building include: (a) the low understanding of politeness among the students, (b) the students' diverse background, (c) the students' habits in using a common Javanese language in the school, d) the low control from the students' guardian. In this case, the students' character is an important factor in the learning process [21-23].

Three factors-teachers, pesantren environment, and internalizing planting attitude - are not absolute. The most important factor that highly determines the Javanese culture-based students' character building is essentially their internal motivation and willingness by themselves. These factors are a central core for a character building. This internal factor is stronger if supported by culture background $[24,25]$ and the management of the dormitory that prioritizes character and moral education in a sincere manner [26-28].

The realization of speech acts of pesantren students in rejecting their teachers is non-literal and indirect. Acting this language illustrates that students in the pesantren environment have very high adherence to the teaching of their teacher. Teachers in the pesantren environment become the models for the students behavior. This condition differs from the way students communicate with their friends which tends to be literal and direct. The culture in pesantren environment also helped shape the santri's religious personality and religious journey. School culture reflects its academic culture $[29,30]$. This is in line with the formulation that children's academic intelligence in school is parallel with the social politeness instilled by teachers in their school environment [31,32].

\section{CONCLUSION}

The results of the study underline several points. First, the refusal speech act realized by the students is mostly indirect strategies rather than direct ones. The findings indicate that the students have a high respect to the teachers, particularly to those who are charismatic in the boarding school environment. Second, the refusal speech act realized by the students is mostly the responses to teacher's instruction and command, instead of advice or role model. It implies the advice/suggestion and role model are the most appropriate methods of indirect strategies to manage the students' learning and religious activities. Third, the concrete efforts that can be carried out by the Islamic boarding school to establish and internalize the students' character building are giving an exemplary, enculturation, supervision, and suggestion. Meanwhile, admonitions and sanctions are used as an intermediate effort in the students' maturation process.

The internalization of the students' character building is affected by the following: (a) the teachers' role in the enculturation of character building in learning activities, (b) the polite character-based circumstance, (c) the character building through learning in the classroom. Meanwhile, the inhibiting factors in the internalization of the students' character building may include: (a) the relatively low understanding of politeness among the students, (b) the diversity of students' background, (c) the students' habits and the background of local languages, and d) the low control from the students' guardian.

\section{ACKNOWLEDGEMENTS}

I would like to thank to the LPPM UMS and to Ristek Dikti Ministry who have provided the grant in the research. Also, I am very grateful to Prof. Madya Dr. Norliza Jamaluddin, Faculty of Language and Communication, Sultan Idris Malaysian Education University and Prof. Dr Jeniri Amir, Faculty of Language Studies and Communication Studies at Universiti Malaysian Sarawak who has provided academic feedback on the article.

\section{REFERENCES}

[1] Aisyah, A. R. The Implementation of Character Education through Contextual Teaching and Learning at Personality Development Unit in The Sriwijaya University Palembang. International Journal of Education and Research. October 2014, Vol. 2 (10), pp. 203-214.

[2] Culpeper, Jonathan. Politeness and Impoliteness. In: Karin Aijmer and Gisle Andersen (eds.) Sociopragmatics, Volume 5 of Handbooks of Pragmatics. Berlin: Mouton de Gruyter, 2011. pp. 391-436.

[3] Mujiyanto, Yan. The Verbal Politeness of Interpersonal Utterances Resulted from Back-Translation Indonesian Texts into English. Indonesian Journal of Applied Linguistics. January 2017, Vol. 6 (2), pp. 288-300.

[4] Adel, Seyyed Mohammad Reza, et al. A qualitative study of politeness strategies used by Iranian EFL learners in a class blog. Iranian Journal of Language Teaching Research, 2016. Vol. 4 (1), pp. 47-72. 
[5] Prayitno, Harun Joko. Teknik dan Strategi Kesantunan Direktif di KalanganAndik SD Berlatar Belakang Budaya Jawa. JurnalTerakreditasiKajian Linguistik dan Sastra, Desember 2011, Volume 22, No.2, pp. 204-218.

[6] Prayitno, Harun Joko. Tindak Kesantunan Berbahasa dalam Dialektika Pembelajaran Pragmatik: Berdaya, Berorientasi, dan Berstrategi Kesantunan Positif. Prasasti III, November 2015, pp.24-34.

[7] Prayitno, Harun Joko. Studi Sosiopragmatik. Surakarta: Muhammadiyah University Press. 2017.

[8] Leech, Geoffrey. The Principle of Pragmatic. [Translation: Oka, M.D.D]. 2011. Jakarta: UI-Press. 2011.

[9] Mahsun, M.S. MetodePenelitian Bahasa. Depok: Rajawali Pers. 2006.

[10] Sudaryanto. Metode dan Aneka Teknik Analisis Bahasa (EdisiRevisi). Yogyakarta: Sanata Dharma University Press. 2015.

[11] Sudaryanto. 2017. Menguak Tiga Faset Kehidupan Bahasa. Yogyakarta: Sanata Dharma University Press.

[12] Kedves, Ana. Face Threatening Acts and Politeness Strategies in Summer School Application Calls. Jezikoslovlje. 2013, Vol. 14. No. 2-3: pp. 431-444.

[13] Ali, Shamim. Authority Relations and Pragmatic Strategies in Disagreement between ESL Learners. International Journal of Humanities and Cultural Studies. 2014, Vol. 1, Issue. 3, pp. 471-480.

[14] Sukarno. Politeness Strategies in Responding to Compliments in Javanese. Indonesian Journal of Applied Linguistics, January 2015, Vol. 4 (2), pp. 91-101.

[15] Sukarno. Politeness Strategies, Linguistic Markers and Social Contexts in Delivering Request in Javanese. Indonesian Journal of Applied Linguistics. January 2018, Vol. 7 (3), pp. 659-667.

[16] Spencer O.H., Jiang. 2010. The Paradox of Communication Sociocognitive Approach to Pragmatics. Pragmatics of Society, 2010, Volume 1, Number 1, pp. 50-73. John Benyamin Publishing Company.

[17] Sunandar, Muhtarom, and Sugiyanti. 2015. "Developing Creative, Innovative, and Polite Learning Model. International Journal of Education and Research. February 2015, Vol. 3 (2), pp. 519-526.

[18] Mahmud, Murni. 2018. Exploring Students' Politeness Perspectives at the State University of Makassar. Journal of Education and Learning (EduLearn), February 2018, Vol.12 (1), pp. 36-43.

[19] Asidigisianti, Surya Patria, and Siti Mutmainah. 2018. Using Textbook Illustration as Media for Developing Character among Primary Students: Some Research-based Suggestion. Journal of Education and Learning (EduLearn), February 2018, Vol. 12, (1), pp. 52-56.

[20] Levinson, Penelope Brown. Politeness and Language. International Encyclopedia of the Social \& Behavioral Sciences, 2nd edition, 2015, Volume 18, pp. 326-330.

[21] Chen, Yupin. Children's early awareness of the effect of interpersonal status on politeness. Journal of Politeness Research, 2017; 13(1): 121-142.

[22] Kecskes, Istvan. Context-dependency and impoliteness in intercultural communication. Journal of Politeness Research, 2017; 13(1), pp. 7-31.

[23] Yasser Al-Shoubul, Marlyna Maros, and Mohamad Subakir Mohd. An Intercultural Study of Refusal Strategies in English between Jordanian EFL and Malay ESL Postgraduate Students. 3L: The Southeast Asian Journal of English Language Studies, 2012, Vol 18 (3): 29 - 39

[24] Zakariya K, Abdullah S and Abd Hamid MS. Methods on Moral Development of Teenagers by Luqman al-Hakim. Journal of Education and Learning. 2013, Vol .7 (2), pp. 75-84.

[25] Yuet, Fanny Kho Chee, Hamidah Yusof \& Syed Ismail Syed Mohamad. 2016. Development and Validation of The teacher Leadership Competency Scale. Malaysian Journal of Learning and Instruction. 2016, Vol. 13 No. 2: 43-69.

[26] Eriko Sato \& Aruna Sharma. Trans languaging in Translation: A Case Study of an English Translation of a Hindi Novel "Godaan". International Journal of Language and Literature. December 2017, Vol. 5, No.2, pp. 132-145. DOI: 10.15640/ijll.v5n2a14.

[27] Kundharu, Saddhono, Nugraheni EkoWardani, and Chafit Ulya. 2015. Sociopragmatics Approach on Discourse Structure of Friday Prayer's Sermon in Java and Madura Island. Journal of Language Literature, 2015, Vol.6. No.1. DOI: $10.7813 / \mathrm{jl} 1.2015 / 6-1 / 6$.

[28] Marlyn, Amaros, Nurul Syafawani Halim. Alerters in Malay and English Speech Act of Request: A Contrastive Pragmatics Analysis. 3L: The Southeast Asian Journal of English Language Studies, 2018, Vol. 24(1):69-83.

[29] Kim, Hyekyeng. The Effects of Pragmatic Instruction on The Pragmatic Awareness and Production of Korean University Students. Indonesian Journal of Applied Linguistics, September 2017, Vol. 7 No. 2, pp. 371-380. doi: dx.doi.org/10.17509/ijal.v7i2.8136.

[30] Munip, Abdul. Uniqueness in Translating Arabic Hagiography of Shaikh 'Abd Al-Qadar Al-Jailani: The Case of An-Nur Al-Burhani. Indonesian Journal of Applied Linguistics, January 2018, Vol. 7 No. 3, pp. 668-675. doi: 10.17509/ijal.v7i3.9817.

[31] Neimneh, Shadi Saleh. Postcolonial Arabic Fiction Revisited: Naturalism and Existentialism in Ghassan Kanafi's Men in The Sun. Indonesian Journal of Applied Linguistics, September 2017, Vol. 7 No. 2, pp. 476-485. doi: dx.doi.org/10.17509/ijal.v7i2.8356.

[32] Mahmud, Murni. 2018. Exploring Students' Politeness Perspectives at the State University of Makassar. Journal of education and Learning (EduLearn). February 2018, Vol.12, No.1, pp. 36 43. ISSN: 2089-9823, DOI: 10.11591/edulearn.v12i1.6926 


\section{BIOGRAPHIES OF AUTHORS}

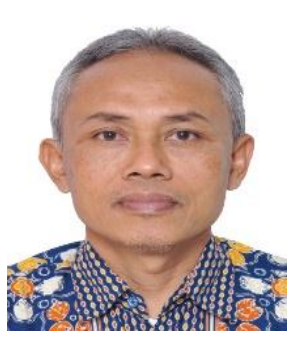

Harun Joko Prayitno, Prof. Dr, a permanent lecturer at FKIP UMS since 1993, was born in Karanganyar on 28 April 1965. He completed the Doctoral Program of UNS in 2008. He is an expertise in a pragmatic teaching in relation to the act of civilized communication. He has actively got the grants of the research schemes, including a Fundamental Research, PUPT, and Competitive Grants funded by Kemeristekdikti (the Ministry of Research and Technology and Higher Education since 1995. His research papers in pragmatics and teaching have widely been presented at various national and international seminars and published in proceedings and and scientific journals. Also, the research results have been written as an instructional material for the students of a higher education.

Email: harun.prayitno@ums.ac.id

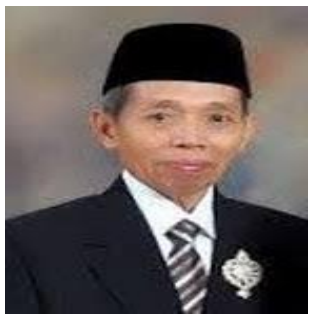

Prof. Dr. Abdul Ngalim is a lecturer of FKIP Muhammadiyah University of Surakarta. He was born in Klaten, December 11, 1946. His primary research interests have included a sociolinguistic and pragmatic field and character education since 1995 . He has got the grants of research schemes, including a Competitive Grant, PUPT, Graduate Grant funded by funded by Kemeristekdikti (the Ministry of Research and Technology and Higher Education. His research papers have been presented at a conference forum and published as an instructional material as well as to various national and international scientific journals.

Email: abdul.ngalim@ums.ac.id

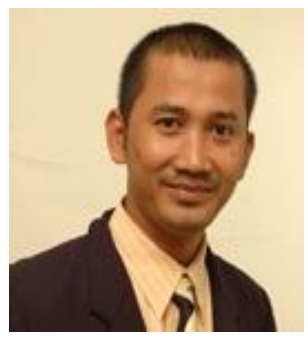

Dr. Muhammad Rohmadi, a permanent lecturer at FKIP UNS, was born in Sragen on October 3, 1976. He has completed a Doctoral Program Study of UGM in 2009. He is an expertise in pragmatic teaching in relation to textual and contextual instruction. His primary research interests include the fields of sociolinguistics, pragmatics, and sociopragmatics by funded by Kemeristekdikti (the Ministry of Research and Technology and Higher Education. His research papers have been presented at various national and international seminars and published as an instructional material and at international scientific journals.

Email: rohmadi_dbe@yahoo.com

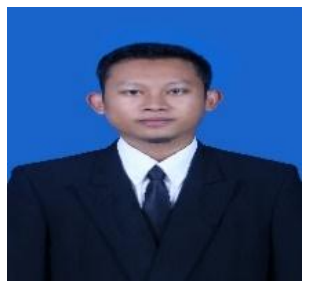

Udik Riyanto, M.Pd. was born in Sragen on January 17, 1990. He has completed the Master's Program of Language Studies, the field of pragmatic and learning process, the Graduate Program of Universitas Muhammadiyah Surakata University. He plays an active role in the Principal Development and Empowerment Institute of Indonesia and pragmatics development in relation to education in the Islamic Boarding School.

Email: udik.riyanto.90@gmail.com 